\title{
THE EFFECT OF GLAUCOMA ON THE QUALITY OF PATIENT'S LIFE
}

Elizabeta Marceta ${ }^{1}$, Dusan Todorovic ${ }^{2,3}$

${ }^{I}$ Department of internal medicine, Clinical hospital center Zvezdara, Belgrade, Serbia

${ }^{2}$ University of Kragujevac, Faculty of Medical Sciences, Department of Ophthalmology, Kragujevac, Serbia ${ }^{3}$ Clinic of Ophthalmology, Clinical Center Kragujevac, Kragujevac, Serbia

\author{
UTICAJ GLAUKOMA NA KVALITET ŽIVOTA PACIJENATA \\ Elizabeta Marčeta ${ }^{1}$, Dušan Todorović ${ }^{2,3}$ \\ ${ }^{I}$ Interna klinika, KBC Zvezdara, Beograd, Srbija \\ ${ }^{2}$ Univerzitet u Kragujevcu, Fakultet medicinskih nauka, Katedra za oftalmologiju, Kragujevac, Srbija \\ ${ }^{3}$ Klinika za oftalmologiju, Klinički centar Kragujevac, Kragujevac, Srbija
}

\section{ABSTRACT}

Glaucoma is a chronic, progressive opticopathy with morphological optic disc changes and visual field disturbances. Visual field disturbances change the patient's life habits. Medical as well as surgical treatments also disturb patients 'activities of daily living. According to this, glaucoma is the disease which affects quality of patient's life ( $Q Q L)$. Visual field $(V F)$ evaluation is very important in glaucoma disease diagnostic process. Location of the $V F$ defects also have an impact on the QOL. Patient's daily activities, such as walking, low light condition adaptation, peripheral seeing of the objects, can be affected by glaucoma progression and with VF defects. All social, religious, cultural and traveling events are more difficult for the severe glaucomatous patients $(M D<-12 d B)$ in comparison with mild glaucomatous, defined as patients with $M D>-6 d B$. Every day usage of the local antuglaucomatous therapy disturbs patients' $Q O L$. The side effects of the eye drops can produce burning sensation, bronchospasm, bradycardia, increased iris pigmentation, increased eyelash length Also, locally applied therapy provokes ocular surface disease. Benzalkonium chloride provokes destruction of the epithelial cells junction with development of the epitheliopathy and ocular surface disease. Surgically treated glaucoma patients can have disturbed QOL due to ocular surface disease symptoms (foreign body sensation, eye pain, redness, and increased tearing). These symptoms are caused by trabeculectomy and they are correlated with filtering bleb existence. To achieve QOL of the glaucomatous patients, different founded instruments are used. They are classified in: general health, vision specific, and glaucoma specific. Keywords: Glaucoma, opticopathy, visual field, optic disc.

\section{SAŽETAK}

Glaukom je hronična, progresivna optikopatija sa morfološkim promenama optičkog diska i poremećajima vidnog polja. Poremećaji vidnog polja menjaju životne navike pacijenta. Hirurški i tretmani lekovima takođe remete svakodnevne aktivnosti pacijenata. Prema tome, glaukom je bolest koja utiče na kvalitet života pacijenta. Procena vidnog polja je veoma važna u dijagnostickom procesu glaukomne bolesti. Lokacija defekata u vidnom polju takođe utiče na kvalitet života. Svakodnevne aktivnosti pacijenta, kao što su hodanje, prilagođavanje uslovima slabog osvetljenja, periferno videnje predmeta, mogu zavisiti od progresije glaukoma i defekata vidnog polja. Svi socijalni, verski, kulturni i putnički događaji izraženiji su kod pacijenata sa težim oblikom glaukoma $(M D<-12 d B)$ u poređenju sa blagim glaukomom, definisanim kao pacijenti sa $M D>-6 d B$. Svakodnevna upotreba lokalne antuglaukomne terapije narušava kvalitet života pacijenata. Neželjeni efekti kapi za oči mogu proizvesti osećaj pečenja, bronhospazam, bradikardiju, povećanu pigmentaciju irisa, povećanu dužinu trepavica. Takođe, lokalno primenjena terapija izaziva bolesti površine oka. Benzalkonijum hlorid izaziva uništavanje spojeva epitelnih ćelija sa razvojem epiteliopatije i bolesti površine oka. Pacijenti sa glaukomom koji su hirurški lečeni mogu imati poremećen kvalitet života zbog simptoma bolesti površine oka (osećaj stranog tela, bol u očima, crvenilo $i$ povećano suzenje). Ovi simptomi su uzrokovani trabekulektomijom i povezani su sa postojanjem filtrirajućeg jastučeta.

Da bi se postigao kvalitet života pacijenata sa glaukomom, koriste se razliciti instrumenti. Klasifikovani su u: opšte zdravstveno stanje, specifični za vid i specifični za glaukom. Ključne reči: Glaukom, optikopatija, vidno polje, optički disk.

\section{ABBREVIATIONS}

ADLs - activities of daily living

ADVS - Activities of Daily Vision Scale

BAK - Benzalkonium chloride

IOP -intraocular pressure

MD - mean deviation

VF - visual field

SIP - Sickness Impact profile

QQL - quality of patient's life 


\section{INTRODUCTION}

Glaucoma is a chronic, progressive opticopathy with morphological optic disc changes and visual field disturbances. Ophthalmologists pay attention to the values of intraocular pressure (IOP), as well as to the changes of the optic head, but they must also pay attention to their subjective experience with the disease. Visual field disturbances change the patient's life habits. Medical as well as surgical treatments also disturb patients` activities of daily living (ADLs). According to this, glaucoma is the disease which affects quality of patient's life (QOL).

The purpose of this paper is to point on effect of glaucoma on QOL of patients (treatment modalities, visual acuity and visual field disturbances, mental health disorders), as well as to review different questionnaires and their implications in QOL evaluation.

\section{FUNCTIONAL DISABILITY AND QOL}

Visual acuity measuring is the first step in the evaluation of the QOL. Despite the evaluation of the central visual acuity, contrast sensitivity, dark adaptation and color vision, visual field (VF) evaluation is more important in glaucoma disease diagnostic process. Some studies suggested that mean deviation (MD) of the patient's better eye on VF is similar to the MD of binocular VF in its influence on QOL, figured out by patient's questioner (1) (2). Comparison of the VF loss of the better eye to the visual loss of both eyes give wrong conclusion for the worse VF results than it is really (3). Disturbed QOL is also in connection to the rate of VF changes development (4). That means that patient with grater rate of VF loss have greater risk for visual acuity abnormalities. Location of the VF defects also can also have the impact on the QOL. Using reachable data, it was reported that inferior VF defects had more influence compared to superior VF defects (2). According to their cognition, inferior VF defects are in correlation with general vision, while superior VF defects are in correlation with near vision difficulties (5).

Patient's daily activities (walking, low light condition adaptation, peripheral seeing of the objects, etc.) can be affected by glaucoma progression and with VF defects (6). Dining difficulties are in association with different cultures. Thus, Eastern population with VF horizontal meridian changes has more dinning difficulties, whereas Western population has dining difficulties with central vision changes (7). Walking difficulties are in connection with inferior VF defects. Recent study suggested that glaucomatous patients had 1.65 times higher traffic accident rate in comparison with health individuals with age and mental status adjustments (8). Left, upper and lower VF disturbances were more common in those patients. Also, driving in fog condition was in greater risk for the traffic accident in glaucomatous patients, especially if the MD on VF testing was below $-9 \mathrm{~dB}$ on better eye (9). Driving simulator examination showed that glaucomatous patients had more eyes and head movements to compensate poor peripheral vision during the test (10). Based on those facts, glaucomatous patients got the more chance to loss the driver's license earlier than no glaucomatous patients (11). Decreased reading ability of the glaucomatous patients is in connection with severe VF changes and contrast sensitivity (12). Difficulties with ADLs coordination broaden to the outdoor activities and relationships. All social, religious cultural and traveling events are more difficult for the severe glaucomatous patients $(\mathrm{MD}<-12 \mathrm{~dB})$ in comparison with mild glaucomatous, defined as patients with MD $>-6 \mathrm{~dB}$ (13). Also, patients' observation of the vision loss is in tight conjunction with different social demographic data. Thus, younger age adults, female sex and patients with lower income indicated for the decreased QOL (14).

\section{MEDICAL GLAUCOMA TREATMENT AND QOL}

Medical treatment of the glaucoma is the first step for the glaucoma. Even after glaucoma surgery, medical treatment can be prescribed. Every day usage of the local therapy disturbed their QOL. Side effects of the local medical therapy can produce side effects as: burning sensation, injection, bronchospasm, bradycardia, increased iris pigmentation, and increased eyelash length. Local applied therapy provokes ocular surface disease, because of the common usage of the preservative, as the constituent of the eye drops (15). Symptoms of the dry eye are the most common symptoms described as the accompanying symptoms among the side effects of the prolonged usage of the anti glaucomatous drugs (16). QOL questionnaires score is decreased in patients with usage more than one kind of the anti glaucomatous eye drops (17). Ocular surface indicator measurements had worse results in glaucomatous patients than in no glaucomatous patients (18). Disturbed tear film stability of the older population, usage of eye drops with preservative, long duration of the treatment increase the incidence of the symptoms of the dry eye in glaucomatous patients (19). Considering the dry eye symptoms development in glaucomatous patients (reduced corneal sensitivity, tear film stability, and basal secretion), artificial tears and corticosteroids must be prescribed to reduce the manifested symptoms (20). If there is no improvement after used therapy, ophthalmologist must think on the BAK allergy, most commonly used eye drops preservative. Benzalkonium chloride (BAK) provokes destruction of the epithelial cells junction with development of the epitheliopathy and ocular surface disease. According to this finding, preservative free antiglaucomatous eye drops must be prescribed (21).

Cost of the treatment can also have the impact on the QOL, regarding to low patients income and lot of other drugs for the other co morbidities (22). All those facts decrease patients' adherence and increase glaucoma progression with decreasing of the QOL. 


\section{SURGICAL GLAUCOMA TREATMENT AND QOL}

Some studies suggested that surgically treated patients had the same QOL in comparison to the medical treated patients, but they have more ocular surface disease symptoms (foreign body sensation, eye pain, redness, and increased tearing). Those symptoms are in correlation with filtering bleb existence (23). It is very interesting to investigate the QOL of the patients who were primary surgical treated (24).

\section{PATIENT REPORTED OUTCOME ON QOL}

Patients need must be in the first plan of the health giving. Patients' reports of the QOL must be detailed examined in order to improve their condition impression. Their impression of the condition differs from patient to patient, with no correlation with clinical measures (25). The QOL of those patients can be in correlation with mental health, living environment, social support, economic status, and co morbidities. To achieve QOL of the glaucomatous patients, different founded instruments can be used (26). Those instruments are classified in: general health, vision specific, and glaucoma specific (26).

General health instruments, used in clinical practice and health studies and economics include: 36 Item Short Form Survey (SF-36) and EuroQol 5 Dimension Scale (EQ-5D). They can be used to access the information about: physical and mental health, self-care, fulfilling necessary daily activities, and pain and discomfort (6) (26).

Some earlier studies indicated that SF-36 usage for evaluation of QOL, was good; but the other studies indicated that was not so valuable and specific for glaucomatous patients (26) (27). Using of EQ-5D in some studies recorded increased pain in glaucomatous patients, mostly in patients with angle closure glaucoma, or with previous glaucoma surgery (28). CIGTS used Sickness Impact profile (SIP) to get QOL assesment, with valuable information about their physical and psychosocial dysfunctions, which can be disturbed in glaucoma (29). QOL was defined as persons' perception of their position in their own life and in the context of their culture and socioeconomic condition of the country they live, by World Health Organization. They made two questionnaires (WHOQOL-100 and 26 item WHOQOL-BREF) which can be used in different countries, with adjustment to different local and socioeconomic settings (30). Visual acuity was not correctly included in general health instruments. Some other instruments were developed to access the impact of ophthalmological disease on QOL- Activities of Daily Vision Scale (ADVS) and the 14-item Visual Function (VF-14), with questions for far and near vision, and for driving potential. Their usage in practice did not show so much benefit for confirming QOL. Thus, Visual Activities Questionnaire (VAQ) and National Eye Institute Visual Functional Questionnaire (NEI-VFQ) was defined to evaluate QOL of ophthalmological patients. VAQ focuses mainly on visual function. NEI-VFQ contains questions on general functional and mental health status that can be deteriorated with decreased vision.

Specific visual and physical functions can be examined using glaucoma specific instruments. Their usage can give us the answer about QOL in correlation with disease severity, specific side effects of used treatment or earlier surgeries (31). Glaucoma Quality of Life (GQL-15) questioner gives the information about glaucoma specific visual and physical functions - dark adaptation and mobility (32). QOL of glaucoma experts developed Symptom and Health Problem Checklist (SHPC) to get different side effects of the applied treatment by counting Symptom Impact Glaucoma (SIG) score. Their usage in practice recorded that patients with earlier glaucoma surgery recorded more local symptoms (swollen eyelids, foreign body sensation). Medical group had more systematic symptoms-sleepiness, disturbed taste. Examiners in CIGTS designed Glaucoma Health Perception Index (GHPI) to get patients observation about their physical, social, and emotional health in correlation with glaucoma and its treatment (23). Also, examiners used Treatment Satisfaction Survey-Intraocular Pressure (TSS-IOP), as tool to get the information about patients satisfaction of used therapy. Most of got data referred to medical effectiveness, medication side effects, the way of drug applying and the rate of ophthalmological controls (33). To get the information about the relative importance of all the aspects of antiglaucomatous treatment and the disease course, examiners used: Linear thermometer scale, time trade off, conjoint analysis, Likert scaling, and Rasch analysis. The EQ-5D visual scale (EQ-VAS) was applied to get the information about patient's self-reported health status (6). Time trade off test patients was used to get the information of their motivation about investment of time and money in good vision. This study recorded that they had good motivation in the case of poor central visual acuity (28). Conjoint analysis is the valuable test for rating the importance of different vision related attributes (central and near vision, darkness and glare, outdoor mobility, household chores, and peripheral vision) (28).

Ophthalmologists made lot of different tests to get the different information about the glaucoma disease and its correlation with patients' way of life, doing daily activities and to measure them on some way. The main goal is to improve their QOL.

\section{ANXIETY AND DEPRESSION OF GLAUCOMA PATIENTS}

Mood disorders of chronic patients (glaucoma) have very big impact on QOL (27) (34). Some studies recorded increased rate of anxiety and depression in glaucoma patients (35) (36) (37). Anxiety of glaucoma patients are in correlation with older age of life, female sex, decreased visual acuity, and decreased central visual acuity (38). Depression of glaucoma patients are in correlation of their own perceptions of the disease and quality of vision (34) (39). Some studies indicated that depression of the glaucoma patients increased with great fear for irreversible blindness, but usage of the 
appropriate medical treatment decreased that (14). Well informed patients about glaucoma disease showed decrease depression rate and good compliance (40). Cognitive disorder in conjunction with anxiety and depression in older patients showed decreased compliance rate (41). All those facts about mental disorders can improve QOL, compliance, IOP control.

Glaucoma is chronic disease, which can lead to irreversible blindness if it is not well treated. QOL of glaucoma patients do not depend only of ophthalmological parameters (visual acuity, intraocular pressure, visual filed changes). The variety of factors can have the impact on QOL: the location of visual fields defects, problems with reading, driving, and daily activities. Also, type of medical treatment can affect QOL, like: discomfort, foreign body sensation, increased tearing, dry eye symptoms, etc. These factors can impact on medical adherence and their perception of QOL. All those factors can be changed during the disease duration: mobility is very important in early stadium, while central vision is more important in late one. Anxiety and depression are in tight conjunction with glaucoma disease development. Medical education about the course of the disease can improve mental condition as well as their attitude to the disease. Measurement of QOL can ameliorate the clinical management and socio economic status in glaucoma.

\section{REFERENCES}

1. Chun Y, Lee DI, Kwon J, et al. Comparison of impact of monocular and integrated binocular visual fields on vision-related quality of life. J Glaucoma. 2017;26:283291.

2. van Gestel A, Webers CA, Beckers HJ, et al. The relationship between visual field loss in glaucoma and health-related quality-of-life. Eye (Lond). 2010;24:1759-1769.

3. Asaoka R, Crabb DP, Yamashita T, et al. Patients have two eyes!: binocular versus better eye visual field indices. Invest Ophthalmol Vis Sci. 2011;52:7007-7011.

4. Lisboa R, Chun YS, Zangwill LM, et al. Association between rates of binocular visual field loss and vision-related quality of life in patients with glaucoma. JAMA Ophthalmol. 2013;131:486-494.

5. Cheng HC, Guo CY, Chen MJ, et al. Patient-reported vision-related quality of life differences between superior and inferior hemifield visual field defects in primary open-angle glaucoma. JAMA Ophthalmol. 2015;133:269-275.

6. Quaranta L, Riva I, Gerardi C, et al. Quality of life in glaucoma: a review of the literature. Adv Ther. 2016;33:959-981.

7. Murata H, Hirasawa H, Aoyama $Y$, et al. Identifying areas of the visual field important for quality of life in patients with glaucoma. PLoS One. 2013;8:e58695.
8. Kwon M, Huisingh C, Rhodes LA, et al. Association between glaucoma and at-fault motor vehicle collision involvement among older drivers: a population-based study. Ophthalmology. 2016;123:109-116.

9. Diniz-Filho A, Boer ER, Elhosseiny A, et al. Glaucoma and driving risk under simulated fog conditions. Transl Vis Sci Technol. 2016;5:15.

10. Kubler TC, Kasneci E, Rosenstiel W, et al. Driving with glaucoma: task performance and gaze movements. Optom Vis Sci. 2015;92:1037-1046.

11. van Landingham SW, Hochberg C, Massof RW, et al. Driving patterns in older adults with glaucoma. BMC Ophthalmol. 2013;13:4.

12. Nguyen AM, van Landingham SW, Massof RW, et al. Reading ability and reading engagement in older adults with glaucoma. Invest Ophthalmol Vis Sci. 2014;55:5284-5290.

13. Yang Y, Trope GE, Buys YM, et al. Glaucoma severity and participation in diverse social roles: does visual field loss matter? J Glaucoma. 2016;25:e697-e703.

14. Janz NK,Wren PA, Lichter PR, et al. Quality of life in newly diagnosed glaucoma patients: the Collaborative Initial Glaucoma Treatment Study. Ophthalmology. 2001;108:887-897 discussion 898.

15. Ramli N, Supramaniam G, Samsudin A, et al. Ocular surface disease in glaucoma: effect of polypharmacy and preservatives. Optom Vis Sci. 2015;92:e222-e226.

16. Pouyeh B, Viteri E, FeuerW, et al. Impact of ocular surface symptoms on quality of life in a United States veterans affairs population. Am J Ophthalmol. 2012;153:1061-1066. e3.

17. Rossi GC, Tinelli C, Pasinetti GM, et al. Dry eye syndrome-related quality of life in glaucoma patients. Eur J Ophthalmol. 2009;19:572-579.

18. Cvenkel B, Stunf S, Srebotnik K, et al. Symptoms and signs of ocular surface disease related to topical medication in patients with glaucoma. Clin Ophthalmol. 2015;9: 625-631.

19. Perez-Bartolome F, Martinez-de-la-Casa JM, ArriolaVillalobos $\mathrm{P}$, et al. Ocular surface disease in patients under topical treatment for glaucoma. Eur J Ophthalmol. 2017;27: 694-704.

20. Terai N, Muller-Holz M, Spoerl E, et al. Short-term effect of topical antiglaucoma medication on tear-film stability, tear secretion, and corneal sensitivity in healthy subjects. Clin Ophthalmol. 2011;5:517-525.

21. Anwar Z, Wellik SR, Galor A. Glaucoma therapy and ocular surface disease: current literature and recommendations. Curr Opin Ophthalmol. 2013;24:136-143.

22. Tsai JC. A comprehensive perspective on patient adherence to topical glaucoma therapy. Ophthalmology. 2009; 116 (suppl):S30-S36.

23. Janz NK, Wren PA, Lichter PR, et al. The Collaborative Initial Glaucoma Treatment Study: interim quality of life findings after initial medical or surgical treatment of glaucoma. Ophthalmology. 2001;108:1954-1965.

24. J Ophthalmol. 2017:1-7. King AJ, Fernie G, AzuaraBlanco A, et al. Treatment of Advanced Glaucoma Study: a multicentre randomised controlled trial 
comparing primary medical treatment with primary trabeculectomy for people with newly diagnosed advanced glaucoma-study protocol. Br.

25. Zimmerman T, Karunaratne N, Fechtner R. Glaucoma: outcomeology (part I, II). J Glaucoma. 1996;5:151-155.

26. Spaeth G, Walt J, Keener J. Evaluation of quality of life for patients with glaucoma. Am J Ophthalmol. 2006;141 (suppl):S3-S14.

27. Wilson MR, Coleman AL, Yu F, et al. Functional status and well-being in patients with glaucoma as measured by the Medical Outcomes Study Short Form-36 questionnaire. Ophthalmology. 1998;105:2112-2116.

28. Aspinall PA, Johnson ZK, Azuara-Blanco A, et al. Evaluation of quality of life and priorities of patients with glaucoma. Invest Ophthalmol Vis Sci. 2008;49:19071915.

29. Khanna CL, Leske DA, Holmes JM. Factors associated with health-related quality of life in medically and surgically treated patients with glaucoma. JAMA Ophthalmol. 2018.

30. Nutheti R, Shmanna BR, Nirmalan PK, et al. Impact of impaired vision and eye disease on quality of life in Andhra Pradesh. Invest Ophthalmol Vis Sci. 2006;47: 4742-4748.

31. Peters D, Heijl A, Brenner L, et al. Visual impairment and vision-related quality of life in the Early Manifest Glaucoma Trial after 20 years of follow-up. Acta Ophthalmol. 2015;93:745-752.

32. Goldberg I, Clement CI, Chiang TH, et al. Assessing quality of life with glaucoma using the Glaucoma Quality of Life-15 (GQL-15) questionairre. J Glaucoma. 2009; 18: 6-12.

33. Day DG, Sharpe Ed, Atkinson MJ, et al. The clinical validity of the treatment satisfaction survey for intraocular pressure in ocular hypertensive and glaucoma patients. Eye (London). 2006;20:583-590.
34. Jampel HD, Frick KD, Janz NK, et al. Depression and mood indicators in newly diagnosed glaucoma patients. Am J Ophthalmol. 2007;144:238-244.

35. Mabuchi F, Yoshimura K, Kashiwagi K, et al. High prevalence of anxiety and depression in patients with primary opan-angle glaucoma. J Glaucoma. 2008;17: 552-557.

36. Tastan S, Iyigun E, Bayer A, et al. Anxiety, depression, and quality of life in Turkish patients with glaucoma. Psychol Rep. 2010;106:343-357.

37. Zhou C, Qian S, Wu P, et al. Anxiety and depression in Chinese patients with glaucoma: sociodemographic, clinical, and self-reported correlates. J Psychosom Res. 2013;75:72-82.

38. Mabuchi F, Yoshimura K, Kashiwagi K, et al. Risk factors for anxiety and depression in patients with glaucoma. Br J Ophthalmol. 2012;96:821-825.

39. Skalicky S, Goldberg I. Depression and quality of life in patients with glaucoma: a cross-sectional analysis using the Geriatric Depression Scale-15, Assessment of Function Related to Vision, and the Glaucoma Quality of Life-15. J Glaucoma. 2008;17: 546-5.

40. Stryker JE, Beck AD, Primo SA, et al. An exploratory study of factors influencing glaucoma treatment adherence. J Glaucoma. 2010;19:66-72.

41. Yochim BP, Mueller AE, Kane KD, et al. Prevalence of cognitive impairment, depression, and anxiety symptoms among older adults with glaucoma. J Glaucoma. 2012;21:250-254. 